\title{
Examining Bread/Biscuit Quality Features in Wheat (Triticum aestivum L.) Genotypes by Raman Spectroscopy
}

\section{Murat Olgun', Yaşar Karaduman², Savaş Belen ${ }^{3}$, Zekiye Budak Başçiftçi ${ }^{4}$, Nazife Gözde Ayter Arpacıoğlu ${ }^{5}$, Okan Sezer*6, Murat Ardıç7, İsmühan Potoğlu Erkara ${ }^{8}$}

${ }^{1}$ Eskişehir Osmangazi University, Agricultural Faculty, Field Crop Department, Eskisehir 26040, Turkey, orcid.org/0000-0002-6234-455X

2Eskişehir Osmangazi University, Agricultural Faculty, Field Crop Department, Eskisehir 26040, Turkey, orcid.org/0000-0003-1306-3572

${ }^{3}$ Transitional Zone Agricultural Research Institute, Eskisehir 26000, Turkey, orcid.org/0000-0001-7357-8127

${ }^{4}$ Eskişehir Osmangazi University, Agricultural Faculty, Field Crop Department, Eskisehir 26040, Turkey, orcid.org/0000-0002-4034-2537

${ }^{5}$ Eskişehir Osmangazi University, Agricultural Faculty, Field Crop Department, Eskisehir 26040, Turkey, orcid.org/0000-0002-5121-4303

${ }^{6}$ Eskisehir Osmangazi University, Faculty of Science and Letters, Department of Biology, Eskisehir 26040,

Turkey, orcid.org/0000-0001-7304-1346

${ }^{7}$ Eskisehir Osmangazi University, Faculty of Science and Letters, Department of Biology, Eskisehir 26040,

Turkey, orcid.org/0000-0001-8734-3038

${ }^{8}$ Eskisehir Osmangazi University, Faculty of Science and Letters, Department of Biology, Eskisehir 26040,

Turkey, orcid.org/0000-0001-5780-4999

*Corresponding author: oksezer@ogu.edu.tr

Received: 27 September 2021, Accept: 19 November 2021, Published Online: 01 December 2021

\begin{abstract}
In this study, the quality characteristics of wheat varieties with bread/biscuit character were determined by Conditional Formatting, Path Analysis and Raman Spectroscopy. In this study, Gerek, Carisma, Bayraktar, Artico and Adv. Line genotypes were used. In the study, protein content, test weight, thousand seed weight, seed diameter, zeleny sedimentation, SRC lactic acid and SRC saccharose, hardness index, damaged starch, Gliadin relative mobility index, Gluten quality band score Raman protein, Raman lipid and Raman starch, GlutoPeak (including PMT, BEM, AM, PM, Aggregation energy and GPI) analyzes were examined. As a result, in our study, it was revealed that it is possible to reveal the biscuit quality of genotypes by using classical quality methods. Especially by using gliadin band fractions and gluten band scores, the gluten quality of the genotypes can be revealed and those with bread or biscuit character can be easily distinguished. By using classical methods together with Raman Spectroscopy, separation in bread/biscuit quality levels in wheat genotypes could be done quickly and reliably, and the Raman Spectrophotometer method can be successfully applied in this field. They could be used successfully to determine the quality levels of protein ratio, sedimentation, gliadin band fraction, gluten properties, GPI, PMT, Aggregation Energy, SRC Lactic acid, Raman protein genotypes. Again, it was
\end{abstract}


determined that the Gerek and Carisma genotypes had good biscuit characteristics and that these cultivars could be used successfully in the biscuit sector.

Key words: Bread/biscuit wheat, Quality characters, Gliadin relative mobility index, Gluten quality band score, Conditional Formatting, Biplot analysis, Raman spektroscopy

\section{Introduction}

Wheat is a plant that has been produced in the world since ancient times and has an important place in the nutrition of the world population. This plant, which has a wide adaptability, is the most widely cultivated and produced plant in the world due to its suitability for taste, ease of transportation and storage, and not troublesome cultivation. As a result of breeding genotypes with high yield and quality have been put forward and offered to the producer (Doğan and Uğur, 2004). When quality is mentioned, high protein content, high taste weight and high sedimentation amount come to mind in wheat. The fact that these are high causes high quality and abundant products to be obtained, especially in bread wheat. Today, with the developing technology, the use of wheat in the industry has diversified and in this context, the biscuit sector has developed itself rapidly (Güngör, 2019). The desired product in the developing biscuit sector is a genotype with high yield, low protein, low sedimentation, but high thousand seed weight and test weight. Considering this need of the biscuit industry, in recent years, some of the improvement studies have shifted to this subject. As a result, biscuit genotypes with high yield, test weight and thousand seed weight, as well as low protein content and sedimentation amount, were developed and offered to the use of the sector.

Biscuit wheat studies are quite new in the world with bread wheat. Genotypes with low protein and sedimentation content, which were used as fodder in the past, are now included in breeding studies to be evaluated in the biscuit sector, and genotypes are being developed in this regard. The most sought-after product in the biscuit industry is the use of genotypes with low protein content and sedimentation amount, high thousand seed weight and test weight. In addition, genotypes with this quality are considered as soft bread wheat. In this study, the quality characteristics of wheat genotypes with bread/biscuit character were evaluated by Conditional Formatting analysis, Biplot analysis and Raman Spectroscopy.

\section{Material and Methods}

In this study, Gerek, Carisma, Bayraktar, Artico and Adv. Line genotypes were used. The characteristics of bread/biscuit wheat genotypes used in the study were given in Table 1. In the study; characteristics, protein content (Anon., 2000), test weight (Vasiljevic and Banasik, 1980), thousand seed weight (Williams et al., 1988), seed diameter (Anon., 2008a), zeleny sedimentation (Anon., 1981), SRC lactic acid and SRC saccharose (Guzman et al., 2015)., hardness index (Anon., 2008b), damaged starch (Anon, 2000), G.R.M.I: Gliadin relative mobility index (Olgun et al., 2015), Glu.Qu.Sc: Gluten quality band score (Olgun et al., 2015), Raman protein, Raman lipid and Raman starch (Piot, et al., 2002; Nawrocka et al., 2015) GlutoPeak (including PMT, BEM, AM, 
PM and Aggregation Energy) (Melnyk et al., 2011; Wiertz, 2018) were examined. Data were evaluated by Conditional Formatting (Anon, 2021), Path Analysis (Yan and Kang, 2002) and Raman Spektroscopy Methods.

Table 1. Characteristics of bread/biscuit wheat genotypes used in the study.

\begin{tabular}{|c|c|}
\hline Genotype & Plant Characteristics \\
\hline Gerek & $\begin{array}{l}\text { Spike type brown and awned, seed white soft, plant height } 100-105 \mathrm{~cm} \text {, winter habit, resistant to } \\
\text { drought and lodging, moderately sensitive to cold, protein content }(\%) 11-12 \text {, thousand seed weight } \\
\text { (gr) } 33-37 \text {, test weight }(\mathrm{kg}) 75-79 \text {, yield (t/ha) } 2.5-5 \text {, resistant to black rust, sensitive to brown rust and } \\
\text { sensitive to yellow rust, bread/biscuit quality, medium for bread, good for biscuits. }\end{array}$ \\
\hline Carisma & $\begin{array}{l}\text { Spike type white and awned, seed red soft, plant height } 80-90 \mathrm{~cm} \text {, winter habit, resistant to drought, } \\
\text { cold and lodging, protein content (\%) } 11-13 \text {, thousand seed weight (gr) } 30-35 \text {, test weight }(\mathrm{kg}): 78-80 \text {, } \\
\text { yield (t/ha) } 3,5-7 \text {, resistant to black rust, brown rust and yellow rust, bread/biscuit quality, good for } \\
\text { biscuit. }\end{array}$ \\
\hline Bayraktar & $\begin{array}{l}\text { Spike type white and awned, seed white semi-hard, plant height } 100-105 \mathrm{~cm} \text {, winter habit, resistant to } \\
\text { drought and lodging, moderately sensitive to cold, protein content }(\%) 11-12 \text {, thousand seed weight } \\
\text { ( } \mathrm{gr}) 36-40 \text {, test weight }(\mathrm{kg}) 79-81 \text {, yield (t/ha) } 3.5-5 \text {, resistant to black rust, brown rust and yellow rust, } \\
\text { bread/biscuit quality, good for bread. }\end{array}$ \\
\hline Artico & $\begin{array}{l}\text { Spike type white and awnless, seed red soft, plant height } 70-80 \mathrm{~cm} \text {, winter habit, resistant to drought, } \\
\text { cold and lodging, protein content (\%) } 11-13 \text {, thousand seed weight }(\mathrm{gr}) 31-35 \text {, test weight }(\mathrm{kg}) 78-80 \text {, } \\
\text { yield (t/ha) 4-7, resistant to black rust, brown rust and yellow rust, bread/biscuit quality, medium for } \\
\text { bread, medium for biscuit. }\end{array}$ \\
\hline Adv. Line & $\begin{array}{l}\text { Spike type brown and awned, seed red hard, plant height } 105-110 \mathrm{~cm} \text {, winter habit, resistant to } \\
\text { drought, cold and lodging, protein content (\%) } 13-14 \text {, thousand seed weight (gr) } 36-39 \text {, test weight } \\
\text { (kg) } 80-81 \text {, yield (t/ha) } 4-7 \text {, resistant to black rust, brown rust and yellow rust, bread/biscuit quality, } \\
\text { very good for bread. }\end{array}$ \\
\hline
\end{tabular}

\section{Results and Discussion}

Quality has become one of the most important factors affecting the price of bread/biscuit wheat. This situation has started to make itself felt in biscuit wheat breeding, which is becoming increasingly important. In particular, with the increase in the use of genotypes with high biscuit quality, an important deficiency will be eliminated in the biscuit sector (Doğan and Uğur, 2004). Until today, the biscuit industry has tried to meet its raw material needs, depending on the preference of using the genotypes that do not have bread quality as biscuits. However, the need for biscuit wheat in the biscuit industry, which is developing at a dizzying pace, has made itself felt (Karaduman and Ercan, 2013; Guzman et al., 2016). In this context, the rapid progress of biscuit wheat breeding studies, and the development and introduction of high quality biscuit registered wheat are very important (Pena, 2012). In our study, the evaluation of bread wheat genotypes according to different quality factors by Conditional Formatting method was given in Table 2. As seen in the conditional formatting analysis (Anon., 2021) shown in the table, the genotypes used in the study were evaluated in terms of protein content and zeleny sedimentation. Protein content and zeleny sedimentation reveal whether the genotype is rich in protein and its richness in subunits such as protein-forming gliadin gluten. Although wheat genotypes with a protein content of more than 12 and a zeleny sedimentation of more than $35 \mathrm{ml}$ are considered bread wheat, the protein content be less than $11 \%$ and zeleny sedimentation less than $35 \mathrm{ml}$ are assumed as biscuit wheat (Atlı et al., 1999). 
Table 2. Evaluation of bread wheat genotypes for different quality factors by Conditional Formatting method.

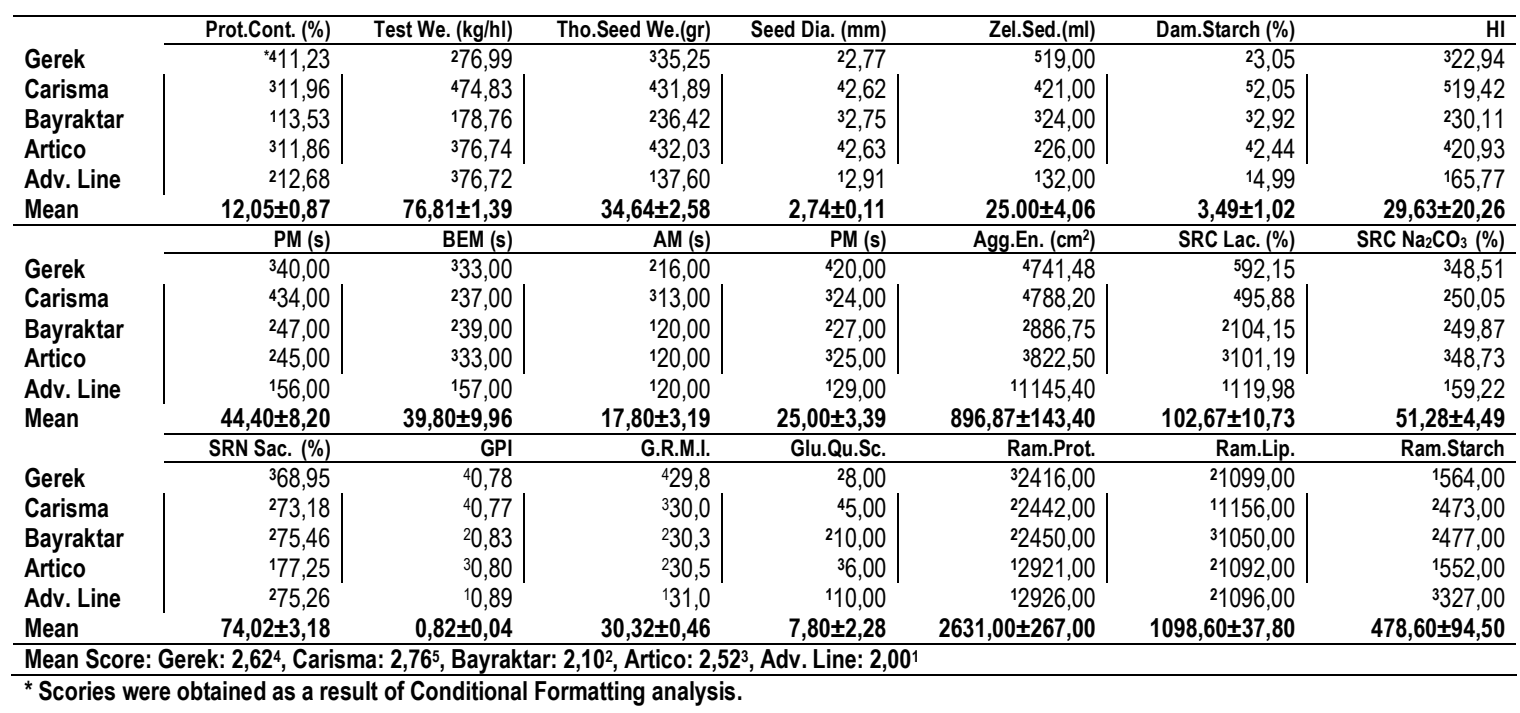

In this respect, in our study, Bayraktar (13,53\%) and Adv. Line (12,68\%) had the highest protein content, while Gerek $(11,23 \%)$ had the lowest protein content. In Zeleny sedimentation, Bayraktar $(26,00 \mathrm{ml})$ had the highest zeleny sedimentation, while Gerek $(19,00 \mathrm{ml})$ had the lowest zeleny sedimentation. Test weight and thousand-seed weight are important characters in the programs both in bread wheat and biscuit wheat, that has gained great momentum in recent years. These two characters of bread wheat are also valid in biscuit wheat breeding. Because both characters show the amount of starch in the seed. Accordingly, genotypes with a high value in terms of test weight and thousand-seed weight are also accepted as acceptable genotypes in biscuit wheat breeding (Atlı et al, 1999; Vasiljevic and Banasik, 1980; Williams et al., 1988). While the genotype is expected to be higher than $80-81 \mathrm{~kg} / \mathrm{hl}$ for test weight, genotypes with a thousand-seed weight of more than $40 \mathrm{~g}$ are accepted for bread/biscuit quality (Akçura, 2011). For test weight, Bayraktar $(78,76 \mathrm{~kg} / \mathrm{hl}$ ) genotype had the highest value, while Carisma $(74,83 \mathrm{~kg} / \mathrm{hl})$ had the lowest value. The genotype with the most value out of a thousand seeds is Adv. Line (37.60 gr) and the lowest value were Carisma (31,89 gr) and Artigo (32,03 gr) genotypes.

Seed diameter not only indicates plant health, but also shows whether the plant is under stress during the development period and whether it is fed regularly. Therefore, the increases and decreases in the seed develop depending on whether the genetic capacity is high or not and the degree of impact of environmental stress (Campbell et al., 1995). Bread/biscuit wheat studies stated that the seed diameter was large enough to indicate that the seed quality was high (Atlı et al, 1999; Campbell et al., 1995). In our study, the highest seed diameter of with 2,91 mm was obtained from Adv. Line, the least diameter values were obtained from Carisma $(2,62 \mathrm{~mm})$ and Artigo $(2.63 \mathrm{~mm})$. Depending on whether the wheat is hard/soft, the flour size fragmentation differs. While larger starch particles are formed in the processing of hard bread wheat into flour; smaller sized starch is formed in soft wheats. The more damaged starch structure formed in hard wheat causes and has a higher water absorption capacity and is more easily hydrolysed by a-amylase. The water holding ability of the 
dough and the production of dextrin are higher, stickier dough is formed. In soft wheat, on the other hand, smaller fractional starch forms result in a lower rate of damaged starch. Less water-holding ability and alpha amylase activity in the dough results in a looser dough structure and consequently low breading ability. Therefore, the biscuit value of genotypes with less damaged starch ratio will be higher (Haridas Rao et al., 1989; Mao and Flores, 2001). In the study, Adv. Line gave with the highest damaged starch value of 4,99, while the lowest value was obtained from Carisma $(2,05)$.

Hardness index is a quality measure that changes depending on the physical and chemical properties of starch and seed protein and is considered as distinguishing factor in wheat quality evaluation. The hardness/softness of the wheat seed are closely related to the way the endosperm is processed in the seed and the way the endosperm is broken down. There is a close relationship between hardness index, protein content and zeleny sedimentation. Therefore, there is a positive relationship between low hardness index value and biscuit quality (Wanjugi et al., 2007). On the other hand, as the seed moisture content increases, the hardness index increases (Yamazaki and Donelson, 1983; Gaines, 1986). In this study, the highest hardness index value was obtained from the Adv. Line with 65,77, while the lowest value was obtained from Carisma $(19,42)$. GlutoPeak analysis, including PMT, BEM, AM, PM and Aggregation energy characters in biscuit wheat studies, has been used effectively in recent years to determine the gluten quality of the genotype. The sub-parameters of this GlutoPeak analysis give an idea about the quality of gluten in the flour. These parameters express gluten quality as; PMT, time in seconds to achieve maximum gluten torque; BEM, maximum torque; $A M$ is the value $15 \mathrm{~s}$ before the maximum torque; PM, value $15 \mathrm{~s}$ after maximum torque; Aggregation energy gluten resistance. High values indicate quality bread, low values indicate biscuit properties (Fu et al., 2017; Karaduman and Savaşlı, 2018). Accordingly, in our study, Adv. Line in PMT (56,00 s), BEM (57,00 s), AM (20,00 s), PM (29,00 s) and Aggregation energy $\left(145,40 \mathrm{~cm}^{2}\right)$ provided more values. Again, Carisma in PM $(34,00 \mathrm{~s})$, Artico and Resource in BEM (33,00 s), Carisma in AM (13,00 s), Rein in PM (20,00 s) and Aggregation Energy need $\left(471,48 \mathrm{~cm}^{2}\right)$.

Solvent retention capacity (SRC) method gives very good results in determining the biscuit properties of the flour in soft biscuit wheat. This method gives good results not only in biscuit wheat, but also in the evaluation of hard wheat with bread character (Dang and Bason, 2006).

This method is used to determine the properties of gluten, damaged starch and pentosanes, which are the three main building blocks of wheat flour. It is used to measure the gluten level of SRC lactic acid, the damaged starch level of SRC $\mathrm{Na}_{2} \mathrm{CO}_{3}$, and the pentosan level of SRC saccharose (Guttieri et al., 2008). In addition, the Gluten performance index (PGI) has been used as a new approach SRC parameter. GPI is calculated with the formula [lactic acid/ (sodium carbonate + sucrose)]. In all SRC parameters examined, high values indicate bread quality and low values indicate biscuit quality (Gao et al, 2006). In our study, the highest values were obtained from; Adv. Line in SRC Lactic acid, SRC $\mathrm{Na}_{2} \mathrm{CO}_{3}$, and GPI $(119,98 \%, 59,22 \%$ and 0,89), Artico $(77,25 \%)$ in SRC Saccharose. The minimum values were taken from; Gerek in SRC Lactic acid, SRC $\mathrm{Na}_{2} \mathrm{CO}_{3}$, and SRC Saccharose $(92,15 \%, 8,51 \%$ and $68,95 \%)$. The lowest GPI was taken from Carisma $(0,77)$.

The concept of quality in wheat is determined under the influence of genotype $x$ environment interaction, depending on the physical, chemical and biological properties of wheat (Campbell et al., 1995; Dang and Bason, 
2006). The low/high protein quality in wheat is determined by the deficiency/excess of some essential amino acids (Mian and Nafzigier, 1992; Campbell et al., 1995). Protein in wheat, which varies between 8-18\%, consists of four subunits: albumin, globulin, gluten-forming glutenin and gliadin (Bollecker and Popineau, 1991; Dang and Bason, 2006). Gluten, the main component of protein, consists of two sub-components: glutenin and gliadin. Albumins and globulins are composed of enzymatic proteins and are mostly found in the embryo. Both gliadins and glutenins that make up gluten are found in the endosperm as storage proteins. Although these two elements make up about $85 \%$ of flour, they play an important role in shaping the quality of wheat (Schober et al., 2002). Low and high molecular weight glutenins play a role in determining bread production quality and dough elasticity (Bollecker and Popineau, 1991). Gliadins play a role in dough formation and shaping bread volume. Due to their highly hydrophobic properties, they help the formation of the tight structure of proteins and their binding to other lipids with glycolipids. Gliadin protein sequences are evaluated as finger print analysis and show a constant and unchanging sequence for each genotype. Therefore, it is used as a reliable method for identification of genotypes (Campbell et al., 1995; Schober et al., 2002). High values in gluten and gliadin structures indicate bread quality, while low values indicate biscuit value (Sinha et al., 1997; Örnebro et al., 2000). On the other hand, the detailed analysis of the examined genotypes in terms of Gliadin band fractions and Gluten quality band scores was given in Table 3. As shown in Tables 2 and 3, Adv. Obtained from Line $(31,00$ and 10,00). The lowest values were obtained from the Gerek $(29,8)$ for Gliadin band fractions and from the Carisma genotype $(5,00)$ for Gluten quality band scores.

Table 3. Analysis of the examined genotypes in terms of Gliadin band fractions and Gluten quality band scores.

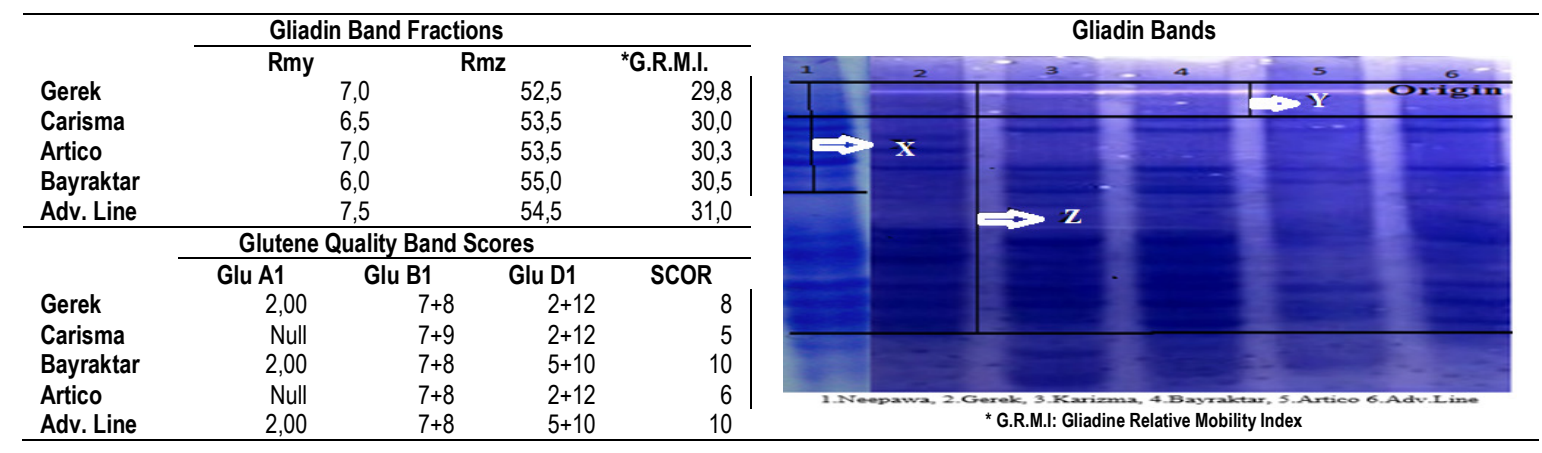

Raman Spectroscopy is classified as vibrational spectroscopy, and it provides the characteristic fundamental vibration to understand the molecular structure of the analysed material. Although Raman spectroscopy gives good results in the symmetric vibration of non-polar groups, it is a full-spectrum and in-depth analysis method for qualitative and quantitative analysis of a wide range of materials (Tuma, 2005). Studies stated that the Raman Spectroscopy method is a method that can be used easily in the characterization and separation of soft and hard bread wheat seeds and flours and can obtain accurate results. In addition, it was revealed that there were differences in the band densities and relative band density ratios of hard wheat flour and soft wheat flour. It has been stated that the protein, lipid and starch band values determined by this method can give an idea about the quality level of the genotype (Tuma, 2005). Raman Spectroscopy showing protein, lipid 
and starch band regions was given in Figure 1, and the Raman protein, Raman lipid and Raman starch Conditional Formatting analyses of the bread wheat genotypes were presented in Table 2.

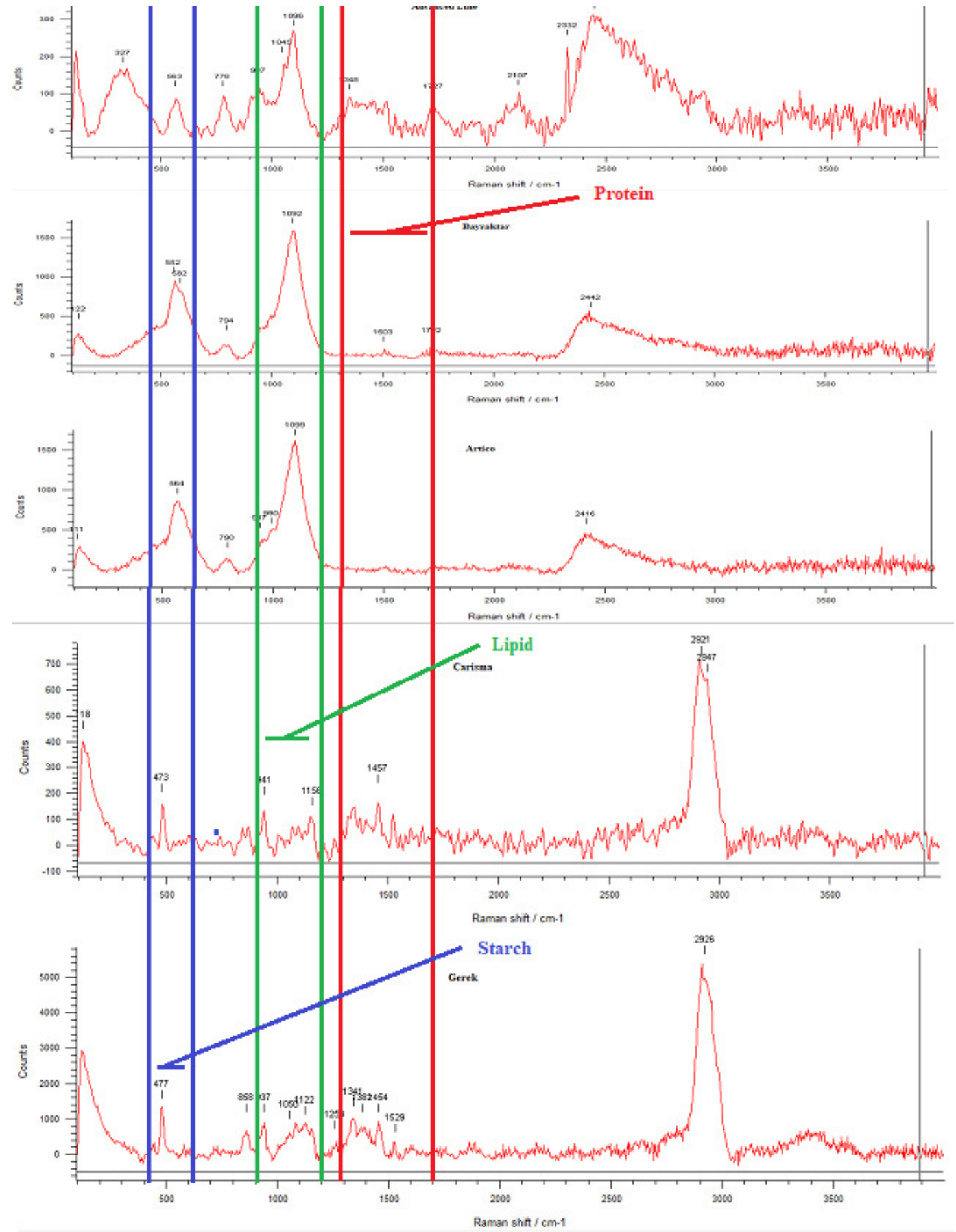

Figure 1. Protein, lipid and starch band regions in Raman Spectroscopy. 
Examining Table 2, the highest values were found on Adv. Line and Artico in Raman protein (2926,00 $\mathrm{cm}^{-1}$ and 2921,00 cm-1), on Carisma (1156,00 $\left.\mathrm{cm}^{-1}\right)$ in Raman lipid and on Gerek (564,00 $\left.\mathrm{cm}^{-1}\right)$ in Raman starch. The lowest values were taken from Gerek $\left(2416,00 \mathrm{~cm}^{-1}\right)$ for Raman protein, Bayraktar for Raman lipid (1050,00 $\left.\mathrm{cm}^{-1}\right)$ and Adv. Line $\left(327,00 \mathrm{~cm}^{-1}\right)$ for Raman starch. Raman Spectroscopy could be used safely to reveal the properties of wheat genotypes in terms of protein, lipid and starch. In particular, the protein quality of the genotypes can be revealed by examining the protein region bands (Shashilov, and Lednev, 2009; Rygula et al., 2013). Therefore, bread/biscuit characteristics of genotypes can be revealed. In Raman Spectroscopy studies performed on wheat flour, it has been reported that amide I (gluten), amide II and amide III, which make up the protein, are found in 1600-1690 $\mathrm{cm}^{-1}, 1480-1580 \mathrm{~cm}^{-1}$ and 1230-1300 $\mathrm{cm}^{-1}$ bands, respectively (Shashilov, and Lednev, 2009). When the protein bands were examined in the Raman Spectroscopy analysis in Figure 1, it can be seen that Carisma and Gerek, Bayraktar and Artico show similar structures. Adv. Line showed a different structure than these. All the analysis results examined above were evaluated according to the Conditional Formatting method (Table 2) and the quality evaluation of the genotypes was made. As a result, Adv. Line genotype showed the best bread characteristics, followed by Carisma and Bayraktar. Gerek and Carisma genotypes showed biscuit characteristics. The Biplot analysis, that reveals the performance and stability of the genotypes considered in our study, and all quality components examined, were given in Figure 2.

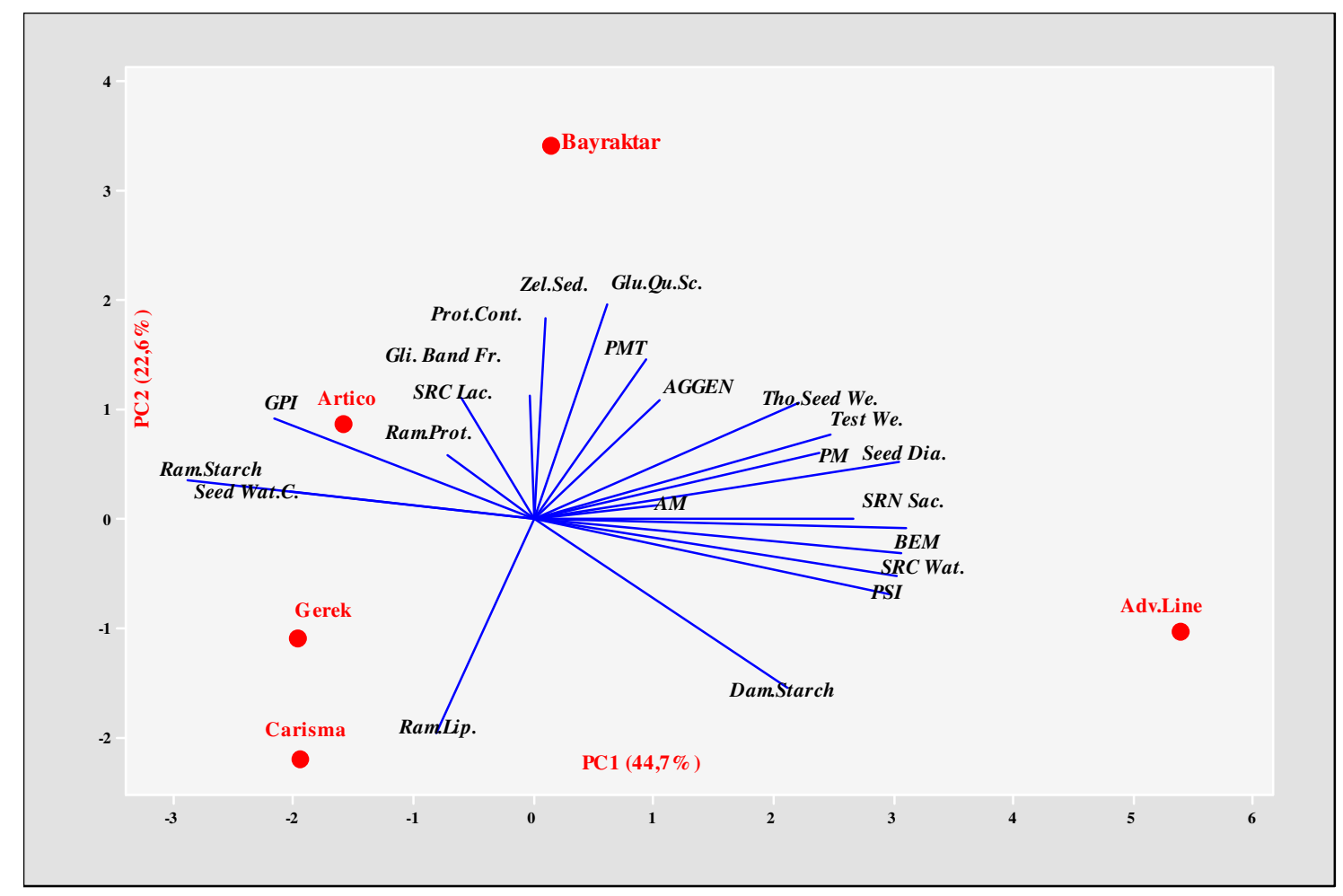

Figure 2. Performance and stability of the genotypes and quality characters in Biplot analysis.

Biplot analysis is a great method that can be applied to various disciplines due to its stated features, revealing the positive or negative performance, capability of the elements under consideration, and whether they 
are also stable in terms of the examined aspects (Karlin et al., 1983). Relationships between the elements examined by Biplot analysis can be revealed with a graphic suitable for the purpose. In this way, the explanation and definition of the relations between the examined elements can be easily done in the framework of logical flow (Martin and Meek, 1986). In this method, the examined elements are interpreted according to the area they occupy in the $x$ and $y$ plane and a two-dimensional analysis is made accordingly, which is one of the characteristic features of Biplot analysis (Singh et al., 1988; Yan and Kang, 2002). In this context, considering the factors and genotypes/genotypes examined in this study, Adv. Line is superior both in terms of performance and stability. Therefore, this genotype is a good genotype in terms of bread quality and it shows that it is in a different group from the others. According to the Biplot analysis, the fact that Artico and Bayraktar genotypes are in the same group indicates that they have similar characteristics. Besides, Gerek and Carisma genotypes were also included in the same group. It can be said that Gerek and Carisma have biscuit character. Artico and Bayraktar genotypes had medium value in terms of biscuit and bread making, therefore they can be used both as biscuits and bread. The fact that protein content, sedimentation, gliadin band fraction, gluten scores, GPI, PMT, Aggregation Energy, SRC Lactic acid, Raman protein values are seen under one group in the Biplot analysis reveals that these quality components could be used successfully in determining the quality levels of genotypes. In addition, the thousand seed eight, test weight, seed diameter, SRN sucrose, hardness index values are under one group reveals that this genotype is a good indicator in revealing the starch quality.

As a result, in our study, it was revealed that it is possible to reveal the biscuit quality of genotypes by using classical quality methods. Especially by using gliadin band fractions and gluten band scores, the gluten quality of the genotypes can be revealed and those with bread or biscuit character can be easily distinguished. In addition, it has been demonstrated in our study that the Raman Spectroscopy method is a method that allows the analysis of genotypes in wheat in terms of bread/biscuit. With the Raman Spectroscopy method, the amount of protein containing Amid I-II-III can be easily determined with the Raman Spectrophotometer, and it can be easily revealed whether it is bread or pasta by considering wavelengths. According to the results obtained, with the use of classical methods together with advanced methods, wheat and durum wheat separation can be done quickly and safely, and the Raman Spectrophotometer method can be successfully applied in this field. It can be used successfully to determine the quality levels of protein ratio, sedimentation, gliadin band fraction, gluten scores, GPI, PMT, Aggregation energy, SRC Lactic acid, Raman protein genotypes. It was also determined that Gerek and Carisma genotypes have good biscuit characteristics and that these genotypes can be used successfully in the biscuit sector. This issue could be revealed in more detail with more detailed studies on these issues.

\section{Conflicts of Interests}

Authors declare that there is no conflict of interests

\section{References}

Akçura, M. (2011). The relationships of some traits in Turkish winter bread wheat landraces. Turkish Journal of Agriculture and Forestry, 35(2), 115-125. 
Anonymous (1981). ICC Standarts. Vienna: International Association for Cereal Chemistry.

Anonymous (2000). AACC Approved Methods (10th ed.). American Association of Cereal Chemists International (AACC), St. Paul, MN.

Anonymous (2008a). AACC International Approved Methods of the AACCI, 11 $11^{\text {th }}$ Edn. The Association, St. Paul, MN.

Anonymous (2021). https://www.sgul.ac.uk/ about/ our-professional-services/ information- services/library/ documents/training- manuals/Excel-Fundamentals-Manual.pdf

Anonymous (2008b). International Association for Cereal Science and Technology (ICC), Vienna Standarts No: $116 / 1$.

Atlı, A., Koçak, N., \& Aktan, M. (1999). Our country's environment quality durum wheat in terms of suitability evaluation. Cereals in Central Anatolia Problems of Agriculture and Solutions Symposium, 345-351, 8-11 June, Konya, Turkey.

Bollecker, S., \& Popineau, Y. (1991). Functional Properties of Deamidated Gliadins. In: Gluten Proteins 1990, Eds. W. Bushuk \& R. Tkachuk, St. Paul, Minnesota, U.S.A.: American Association of Cereal Chemists Inc., p.29-41.

Campbell, L. D., Boila, R. J., \& Stothers, S. C. (1995). Variation in the chemical composition and test weight of barley and wheat grain grown at selected locations throughout Manitoba. Canadian Journal of Animal Science, 75(2), 239-246.

Dang, J. M. C., \& Bason, M. L. (2006). Assessing solvent retention capacities of flours using the Rapid Visco Analyser. Tech. J. Newport Scientific 7, July.

Doğan, İ. S., \& Uğur, T. (2004). A Research on Biscuit Quality of Some Wheat Grown in Van and Its Surroundings. Journal of Agricultural Sciences, 15(2): 139-148.

Fu, B. X., Wang, K., \& Dupuis, B. (2017). Predicting water absorption of wheat flour using high shear-based GlutoPeak test. Journal of Cereal Science, 76, 116-121.

Gaines, C. S. (1986). Texture (hardness and softness) variation among individual soft and hard wheat kernels. Cereal Chemistry, 63(6), 479-484.

Gao, M., Zhang, G., Ni, F., Luo, Q., Wei, Y., \& Zhang, J. (2006). The relationship between micro-SRC value and wheat quality. Journal of Northwest Sci-Tech University of Agriculture and Forestry, 34(12), 87-91.

Güngör, H. (2019). Allelic variations and agronomic comparisons of durum wheat cultivars under EastMediterranean conditions. International Journal of Agriculture and Biology, 21, 891-898.

Guttieri, M. J., Souza, E. J., \& Sneller, C. (2008). Nonstarch polysaccharides in wheat flour wire-cut cookie making. Journal of Agricultural And Food Chemistry, 56(22), 10927-10932.

Guzmán, C., Posadas-Romano, G., Hernández-Espinosa, N., Morales-Dorantes, A., \& Peña, R. J. (2015). A new standard water absorption criteria based on solvent retention capacity (SRC) to determine dough mixing properties, viscoelasticity, and bread-making quality. Journal of Cereal Science, 66, 59-65. 
Guzman, C., Peña, R. J., Singh, R., Autrique, E., Dreisigacker, S., Crossa, J., ... \& Battenfield, S. (2016). Wheat quality improvement at CIMMYT and the use of genomic selection on it. Applied \& Translational Genomics, 11, 3-8.

Karaduman, Y., \& Savaslı, E. (2018). Some practices using glutopeak tester: A High shear gluten quality evaluation method. In 13th Gluten Workshop. Poster Presentation, March, Book of Abstracts (Vol. 115).

Karaduman, Y., \& Ercan, R. (2013). Fast And Easily Applicable Quality Parameters For Soft Wheat Breeding. International Plant Breeding Congress. Book of Abstracts, p.346,10-14, November, Antalya.

Karlin, S., Cameron, E.C., \& Chakraborty, R. (1983). Biplot analysis in genetic epidemyology: a critique. American Journal of Human Genetics, 35, 695-732.

Mao, Y., \& Flores, R. A. (2001). Mechanical starch damage effects on wheat flour tortilla texture. Cereal Chemistry, 78(3), 286-293.

Martin, S. W., \& Meek, A.H. (1986). A Biplot model of factors influencing morbidity and mortality in ontorio feedlot Calves. Canadian Journal of Veterinary Research, 50, 15-22.

Melnyk, J. P., Dreisoerner, J., Bonomi, F., Marcone, M. F., \& Seetharaman, K. (2011). Effect of the Hofmeister series on gluten aggregation measured using a high shear-based technique. Food Research International, 44(4), 893-896.

Mian, A. R., \& Nafziger, E. D. (1992). Seed size effects on emergence, head number, and grain yield of winter wheat. Journal of production Agriculture, 5(2), 265-268.

Nawrocka, A., Szymańska-Chargot, M., Miś, A., Ptaszyńska, A. A., Kowalski, R., Waśko, P., \& Gruszecki, W. I. (2015). Influence of dietary fibre on gluten proteins structure-a study on model flour with application of FT-Raman spectroscopy. Journal of Raman Spectroscopy, 46(3), 309-316.

Olgun, M., Yorgancilar, Ö., Uzun, P., Başçiftçi, Z. B., Ayter, N. G., Koyuncu, O., \& Ardiç, M. (2015). Determining differences between physiologic and, quality characters, gliadin and glutenin electrophoretic bands in bread wheat. Custos E Agronegocio On Line, 11(2), 155-170.

Örnebro, J., Nylander, T., \& Eliasson, A. C. (2000). Critical review-Interfacial behaviour of wheat proteins. Journal of Cereal Science, 31(2), 195-221.

Pena, R. J. (2012). Wheat-end Use Quality Seed Compositional Factors and Seed Quality Improvement. Wheat Quality Workshop 21-26, May, Ankara.

Piot, O., Autran, J. C., \& Manfait, M. (2002). Assessment of cereal quality by micro-Raman analysis of the grain molecular composition. Applied Spectroscopy, 56(9), 1132-1138.

Haridas Rao, P., Leelavathi, K., \& Shurpalekar, S. R. (1989). Effect of damaged starch on the chapatimaking quality of whole wheat flour. Cereal Chemistry, 66(4), 329-333.

Rygula, A., Majzner, K., Marzec, K. M., Kaczor, A., Pilarczyk, M., \& Baranska, M. (2013). Raman spectroscopy of proteins: a review. Journal of Raman Spectroscopy, 44(8), 1061-1076.

Schober, T. J., Clarke, C. I., \& Kuhn, M. (2002). Characterization of functional properties of gluten proteins in spelt cultivars using rheological and quality factor measurements. Cereal Chemistry, 79(3), 408-417. 
Shashilov, V. A., \& Lednev, I. K. (2009). Two-dimensional correlation Raman spectroscopy for characterizing protein structure and dynamics. Journal of Raman Spectroscopy: An International Journal for Original Work in all Aspects of Raman Spectroscopy, Including Higher Order Processes, and also Brillouin and Rayleigh Scattering, 40(12), 1749-1758.

Singh, R. V., Tewari, N., Singh, C. V., \& Singh, Y. P. (1988). Biplot coefficient analysis of mineral in blood serum affecting first lactation milk yield in crossbred cows. Indian Journal of Animal Sciences, 58, 994996.

Sinha, N. K., Yamamoto, H., \& Ng, P. K. (1997). Effects of flour chlorination on soft wheat gliadins analyzed by reversed-phase high-performance liquid chromatography, differential scanning calorimetry and fluorescence spectroscopy. Food Chemistry, 59(3), 387-393.

Tuma, R. (2005). Raman spectroscopy of proteins: from peptides to large assemblies. Journal of Raman Spectroscopy: An International Journal for Original Work in all Aspects of Raman Spectroscopy, Including Higher Order Processes, and also Brillouin and Rayleigh Scattering, 36(4), 307-319.

Vasiljevic, S., \& Banasik, O. J. (1980). Quality Testing Methods for Durum Wheat and Its Products. Department of Cereal Chemistry and Technology, Fargo, North Dakota: North Dakota State University, p.134.

Wanjugi, H. W., Martin, J. M., \& Giroux, M. J. (2007). Influence of puroindolines A and B individually and in combination on wheat milling and bread traits. Cereal Chemistry, 84(6), 540-547.

Wiertz, J. (2018). GlutoPeak methods-RFC. In: Wiertz, J. (Ed.), Brabender® GmbH \& Co. KG -Sales Seminar 2018 GlutoPeak Methods-a Quick Overview, pp.7-13 Germany.

Williams P., El-Haramein, J. F., Nakkoul, H., \& Rihawi, S. (1988). Crop Quality Evaluation Methods and Guidelines. Syria: International Center For Agricultural Research in The Dry Areas (ICARDA).

Yamazaki, W. T., \& Donelson, J. R. (1983). Kernel hardness of some US wheats. Cereal Chemistry, 60(5), 344-350.

Yan, W., \& Kang, M. S. (2002). GGE Biplot Analysis: CRC Press; A Graphical Tool for Breeders, Geneticists, and Agronomists. 